\title{
RURAL
}

NEETs

IN

ITALY

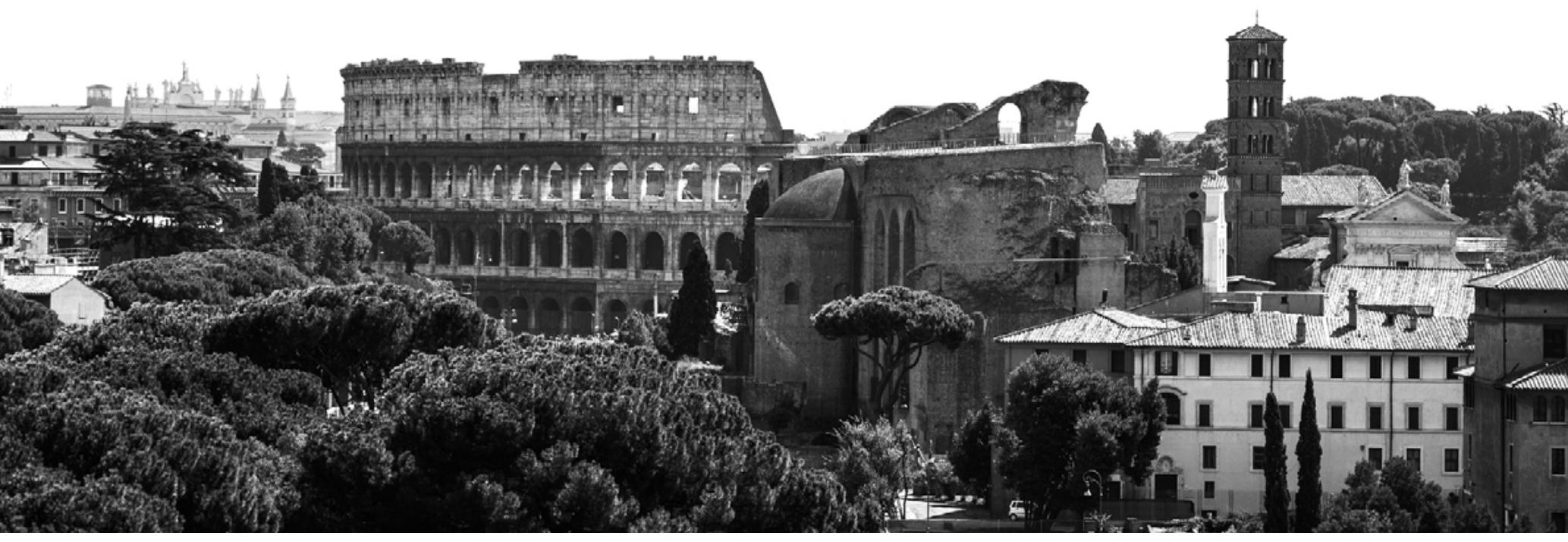

\section{9/2019 OVERVIEW}




\section{AUTHORS}

Sara Alfieri - sara.alfieri@unicatt.it

Università Cattolica del Sacro Cuore - Milano - UCSC

Adriano Mauro Ellena - adrianomauro.ellena@unicatt.it

Università Cattolica del Sacro Cuore - Milano - UCSC

Image by Ichigo121212 from Pixabay

This document is published by COST Action CA 18213: Rural NEET Youth Network: Modeling the risks underlying rural NEETs social exclusion.

(c) COST CA18213, December 2020.

Reproduction is authorized provided the source is acknowledged. Please cite this publication as "COST CA18213 Rural NEETs in Italy: 2009/2019 Overview.

ISBN: 978-989-781-420-4

Visit: www.rnyobservatory.eu 


\section{INDEX}

$\begin{array}{ll}\text { 1. CONTEXTUALIZATION } & 7\end{array}$

$\begin{array}{ll}\text { 1. 1. General information } & 7\end{array}$

2. METHODOLOGICAL NOTE

$\begin{array}{lr}\text { 3. DATA ANALYSIS } & 13\end{array}$

3. 1. Population and youth population 13

3. 2. Employment and Unemployment 17

$\begin{array}{ll}\text { - } \quad \text { Youth employment } & 17\end{array}$

- Youth unemployment $\quad 21$

$\begin{array}{ll}\text { 3. 3. Education } & 25\end{array}$

- Young people by educational attainment level 25

- Early school leavers 30

3. 4. NEETs

- NEET rate $\quad 32$

$\begin{array}{lr}\text { 4. CONCLUSIONS } & 37\end{array}$

$\begin{array}{lr}\text { 5. REFERENCES } & 39\end{array}$

6. IMPORTANT LINKS 


\section{EXECUTIVE SUMMARY}

This document describes the Italian situation of young people aged between 15 and 34 years who do not work, do not study and are not in training (NEET), from 2009 to 2019. The report analyses the following indicators of the youth population: employment; unemployment; education; and, distribution of NEETs. The criteria adopted to analyse data are mainly the degree of urbanisation, the age group and, where possible, gender.

The statistical procedure adopted for the different dimensions selected is descriptive longitudinal analysis and calculation of absolute and relative proportional changes between 2009 and 2013, 2013 and 2019 and between 2009 and 2019. These time intervals have been chosen to capture the evolution of the indicators before and after the economic crisis that hit European countries. All data has been extracted from Eurostat public data sets.

The data analysed shows how the Italian population decreased slightly between 2009 and 2019. However, what clearly changed is the distribution: increased in rural areas and decreased in cities. Youth unemployment grew strongly from 2009 to 2014, until finally decreasing from 2014 to 2019. Between 2009 and 2019, the Italian population aged from 15 to 24 years old has become more educated. The number of young people who drop out of school early decreased sharply, although rural areas remain the ones with the highest rates thereof. Finally, the NEET rate is one of the highest in the EU and has increased overall from 2009 to 2019. The peak was reached in 2014 and then the share decreased until 2019. Rural areas have the highest rate, although with a very small difference compared to the rate of cities and the national average. 


\section{RIASSUNTO ESECUTIVO}

Il presente documento descrive la situazione italiana dei giovani che non lavorano, non studiano e non sono in formazione (NEET) di età compresa tra i 15 e i 34 anni, tra il 2009 e il 2019. Il report analizza i seguenti indicatori della popolazione giovanile: occupazione, disoccupazione, istruzione e distribuzione dei NEET. II criteri adottati per analizzare questi indicatori sono pincipalmente il grado di urbaniziszazione, la fascia di età e, laddove possible, il genere.

La procedura statistica adottata per le diverse dimensioni selezionate è l'analisi longitudinale descrittiva e il calcolo delle variazioni proporzionali assolute e relative tra il 2009 e il 2013, il 2013 e il 2019 e tra il 2009 e il 2019. Questi intervalli di tempo sono stati scelti per catturare l'evoluzione degli indicatori prima e dopo la crisi economica che ha colpito i paesi europei. Tutti i dati sono stati estratti da set di dati pubblici di Eurostat.

I dati analizzati mostrano come popolazione italiana sia leggermente diminuita tra il 2009 e il 2019. Ciò che si modifica nettamente è la distribuzione: aumentata nelle aree rurali e diminuita nelle città. La disoccupazione giovanile subisce una forte crescita dal 2009 al 2014, per poi descresere dal 2014 al 2019. Tra il 2009 e il 2019, la popolazione italiana tra i 15 e i 24 anni è diventata più istruita. I giovani che abbandonano precocemente la scuola diminuiscono fortemente, anche se le zone rurali rimangono quelle con il tasso più alto. Infine, la percentuale di NEET è tra le più alte in UE ed è aumentata complessivamente dal 2009 al 2019. II picco massimo lo si raggiunge nel 2014, per poi decrescere fino al 2019. Le aree rurali presentatno il tasso più elevato, anche se con una differenza esigua rispetto al dato delle città e alla media nazionale. 


\section{INTRODUCTION}

This report proceeds in three sections. It begins with an introductory contextualisation with the most relevant information about Italian social, economic and political situation and key youth policies based on a relevant literature review. A methodological note explains the database used and the statistical operations undertaken. The most extensive section of the report refers to the analysis performed, with a specific focus on young people, by degree of urbanisation and concerning four main topics: population; employment; education; NEETs.

The report ends with a brief conclusion that highlights the main results regarding the topics explored. 


\section{CONTEXTUALIZATION}

\section{1. General information}

Italy is a peninsula located in southern Europe. Since its conformation resembles a boot with the toe pointing southwest, people usually refer to it by this nickname i.e., 'the boot'. To the north, it is bounded by the Alps and borders, from west to east, with France, Switzerland, Austria, and Slovenia. However, most of the territory is surrounded by the Mediterranean Sea, including numerous islands, two of which are autonomous regions (Sicily and Sardinia). Within the Italian territory, the states of Vatican City, San Marino (enclaves of the Republic), and Campione d'Italia (exclave) can be found. Italy is the third largest country in the European Union by population (after Germany and France), with a total of $60,359,546$ inhabitants. (Bilancio demografico Istat http://www.demo.istat.it/bilmens2018gen/). It is characterised by many older people (the old-age index is 161.4), a low fertility rate (1.34), and a life expectancy of 80.6 years for men and 85.1 years for women. (www.dati.istat.it ).

Italy is a parliamentary republic, whose Constitution was approved by the Constituent Assembly on December 22nd, 1947, which came into force on January 1st, 1948, and forms the Republic's founding legal framework. The Italian legal system is bicameral: the Parliament is composed of the Chamber of Deputies and the Senate of the Republic, each having the same powers. In the Italian political system, the President of the Council of Ministers is appointed by the President of the Republic to form the government, for which he is responsible within the Parliament. The President of the Republic is the Head of State, the guarantor of the Constitution, and representative of national unity. He is not the head of one power (legislative, executive, or judicial) but rather coordinates them all.

The administrative structure of the country includes territorial entities which, together with the State, constitute the Italian Republic. These include: 20 regions (15 with an ordinary statute and 5 with a special statute); 14 metropolitan cities; 93 provinces and 7904 municipalities (ISTAT data for the year 2020).

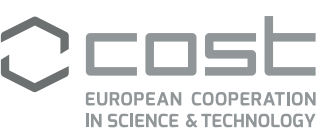


Italy is also a founding member of the European Union, NATO, the Council of Europe, and the OECD and is a UN and Schengen Treaty member. It is also a member of the G7 and G2O.

2. Strategic National legislation for youth: Although there is no unequivocal indication as to who should be defined as "young people", ISTAT includes in this category people between 15 and 34 years old. (http://dati-giovani.istat.it/). However, sociological and psychological literature prefers to use non-biological markers to define it, but rather indicators of transition, such as: the conclusion of studies; entry into the labour market and the acquisition of a relatively stable occupation; housing independence from the family of origin; and, the creation of one's own family. Due to the low fertility rate, this segment of the population is numerically lower than its predecessors. Demographic forecasts also predict a further decline in the coming decades, both in absolute terms and concerning the elderly population. (http://www4.istat.it/it/giovani/popolazione-e-famiglie).

After the reform of Italian family law in 1975, the age of majority is acquired at 18 and one day (previously, the threshold was 21). All Italian citizens over the age of majority are automatically entered on voters' lists in the Chamber of Deputies. By contrast, only those who have reached 25 can vote in elections for the Senate of the Republic.

Compared to other sectors, youth policies in Italy are relatively recent and have developed on multiple levels: the Central Government, Regions, and Autonomous Provinces agree on the drafting of legislation, while local authorities, the third sector, and youth organisations are actively involved in "bottom-up" planning and implementation.

\section{(https://eacea.ec.europa.eu/national-policies/en/content/youthwiki/overview-italy).}

The Department for Youth Policy and Universal Civil Service forms the support structure for the President of the Council of Ministers. It exists to promote and connect government actions in order to ensure the implementation of policies in favour of youth and universal civil service as well as conscientious objection. (https://www.politichegiovanilieserviziocivile.gov.it/sx/dipartimento/competenze.aspx). Since 2006, the National Youth Policy Fund has been funding measures aimed at promoting various measures, including: non-formal 
and informal education; access of young people to the labour market, including the development of start-ups and youth entrepreneurship; social inclusion and specific measures to reach marginalised and vulnerable groups; participation and rights of young people; cultural activities, talent development; prevention and measures against addiction; and, volunteering and access to international and European programs and projects.

In 2019, the Minister put forward the following national policy priorities: social inclusion, participation; support for young people; prevention, and measures against new addictions.

3. Education: Within Italy, education is composed of multiple legal forms: public schools, charter schools and private schools. Professional training is region-specific; the other types depend on the State. The Italian school system is structured in three educational cycles: primary, which lasts five years; secondary, which includes first level secondary school, which lasts three years, and second level secondary school, which lasts five years; higher level, which includes university and specialist training, such as master and specialisation school. In addition to these cycles of education, there is also pre-school, a non-mandatory pre-school institution, characterised by play and cohabitation with classmates and preparation for the first cycle of education. Mandatory schooling is set at 16 years old (www.miur.it).

After the reform introduced by the Bologna Process, the university cycle of studies is divided into three phases: degree (3 years), master's degree (2 years), Ph.D. (3 years).

Compared to other major European economies, Italy is characterised by modest education and skills, although this is growing. As a result, there is a lower incidence in professionals and technicians' employment and personnel with university degrees in these categories. (https://www.istat.it/storage/rapporti-tematici/conoscenza2018/Rapportoconoscenza2018.pdf).

4. Employment: It is possible in Italy to start working from the age of 16 , but age is only one of the requirements. Beginning in 2013, the Department for Youth Policies and Universal Civil Service signed agreements with the Regions for the implementation of direct interventions. These interventions aimed to create Centres/Forms of youth aggregation, aimed at 
improving young people's encounters, the prevention of youth hardship, and the support of young talents (funding actions to support young people in the expression of their talent and creativity), as well as orientation and placement activities. (https://www.politichegiovanili.gov.it/attivita/accordi-e-compartecipazioni/regioni/).

Italy is also a member of the Youth Guarantee, a program launched in 2013 to reduce youth unemployment through European funds. (https://ec.europa.eu/social/main.jsp?catl$d=1161$ \&langld=en\&intPageld=3340). 


\section{METHODOLOGICAL NOTE}

\section{Italy}

The Italian national report uses information gathered by the National Reports Editorial Team of the Rural NEET Youth Network via the Eurostat platform. The main data presented and analysed in this report are from the following Eurostat database:

- Population Statistics: [yth_demo_020]

- EU Labour Force Survey (EU-LFS): [lfst_r_pgauwsc]; [lfst_r_ergau]; [Ifst_r_urgau]; [edat_Ifs_9913]; [edat_Ifse_30]; [edat_Ifse_29]

Selected indicators were extracted from the different databases according to two criteria:

- Time range: the previous decade (2009-2019) in order to have a sufficiently long period of time to capture the main changes and continuities in young people trajectories in education, training and employment. The analysis mainly covered 3 dates - 2009-2013-2019 - in order to capture the impact of the economic and financial crisis that hit Europe and that, in most countries, reached its peak in 2012/2013.

- Age group: age group range varies accordingly to the data available in each indicator (15-24; 15-29; 15-34; and 15-39). Whenever possible, age range also covered young adult's data (30-34 and 35-39) in order to capture the extent of crisis impact on these age groups.

In addition to a descriptive analysis, in order to compare data main changes and continuities in different time periods, absolute and relative change were calculated according to the three main time points that were selected - 2009, 2013 and 2019. Absolute change refers to 
the simple difference in the indicator over two periods in time and is expressed in percentage points (pp). Relative change expresses the change of a value of an indicator in an earlier period and is expressed in percentage terms.

The report also includes an introductory contextualisation section with the most relevant information about the Italian social, economic and political situation as well as key youth policies based on a review of relevant literature and the Youth Wiki European online encyclopaedia. 


\section{DATA ANALYSIS}

\section{1. Population and youth population}

Table 1 presents the data describing the Italian population aged between 15 and 64 , focusing on gender and urbanisation. The years taken into account are 2009, 2013, and 2019. Comparisons are also considered.

In 2009, the total population (15-64) was 38,911,800 inhabitants, of which $16,803,600$ living in cities, $16,363,500$ residing in towns and suburbs, and $5,744,700$ residing in rural areas.

Regarding 2013 , the total population was $39,171,600$ inhabitants, of which $12,658,200$ living in cities, 17,054,800 residing in towns and suburbs, and 9,458,600 living in rural areas.

On the other hand, in 2019 , the total population was $38,427,500$ inhabitants, of which $12,656,900$ residents were living in cities, $16,577,300$ residents living in towns and suburbs, and $9,193,300$ residents living in rural areas.

Comparing the annual surveys, it is clear that in 2013 there was a $24.70 \%$ reduction in the city resident population compared to 2009 (4,145,400 fewer people). The villages and suburbs have instead undergone a slight increase of $4.20 \%$ (691,300 people). Simultaneously, the most surprising figure is recorded in rural areas, where there is a clear increase in the population of $64.60 \%$, corresponding to a rise of $3,713,900$ people. In 2019 , the number of people living in the cities remained almost the same compared to 2013. On the other hand, towns and suburbs and rural areas both suffered a decrease of $2.80 \%$. If we consider the number of inhabitants, we can say that there has been a decrease of 477,500 and 265,300 people respectively.

Overall, from 2009 to 2019, the cities' population decreased by $24.70 \%(4,146,700$ inhabitants), while that of towns and suburbs increased by $1.30 \%$. Again, the most salient range 
comes from rural areas, where the overall increase was $60.00 \%$, corresponding to a rise of $3,488,600$ inhabitants.

With reference to gender, there are no particular differences. Both relative and absolute data seem to be very similar between males and females.

Table 1. Ratio of total population (15-64) by gender and degree of urbanisation, absolute and relative change in Italy (2009-2013, 2013-2019 and 2009-2019)

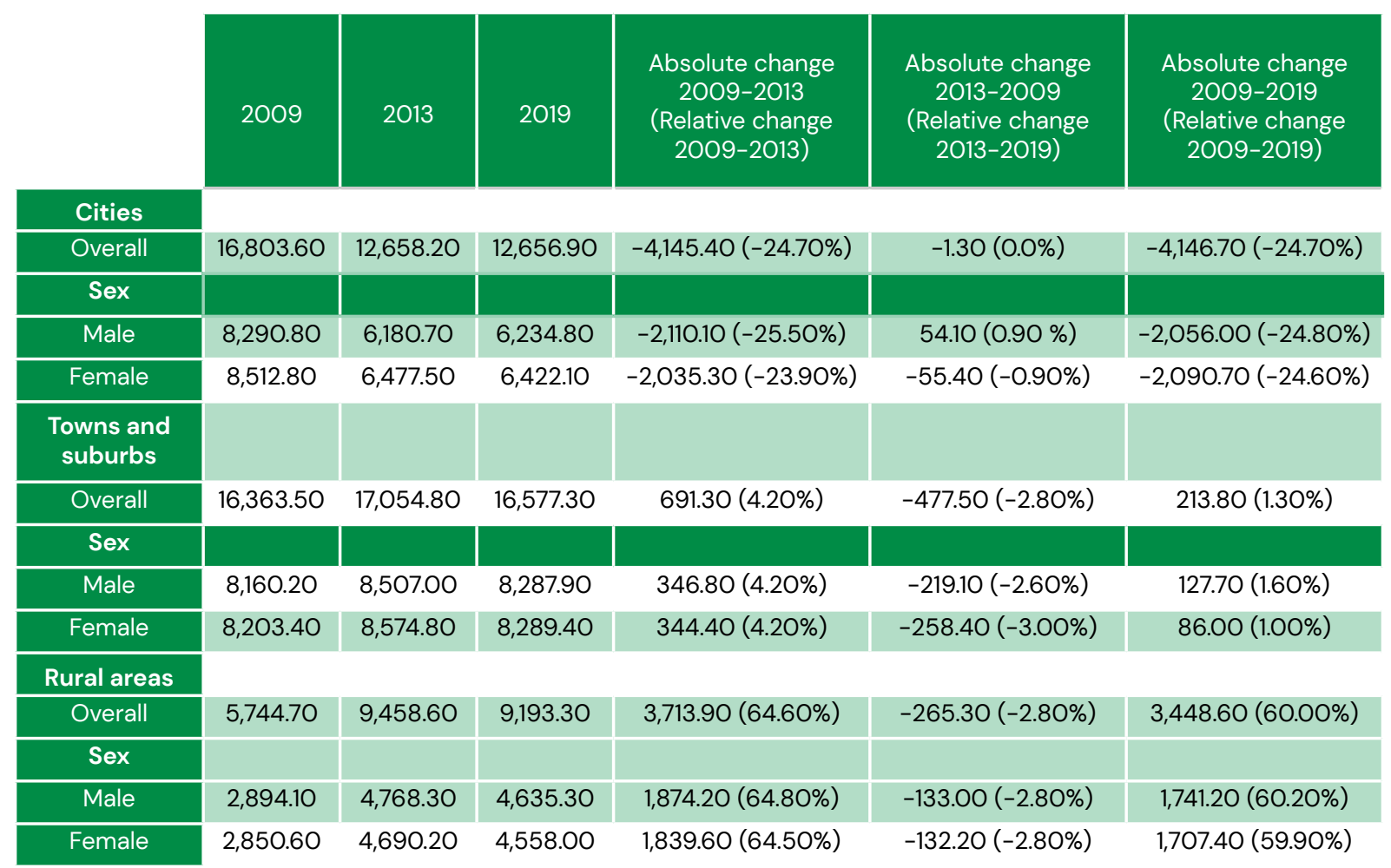

Source: Eurostat (Ifst_r_pgauwsc) - data extracted on 12.05.2020 
The chart below highlights the evolution of the total Italian youth population aged 15-24 years old for different degrees of urbanisation, between 2009 and 2019. According to the chart, the total youth population is slightly declining. In 2009 , there were 5,979,200 people aged $15-24$ in Italy; that number increased to $5,996,100$ by 2013 , and then declined to $5,871,300$ in 2019. In terms of the degree of urbanisation, in 2009 , the largest number of young people resided in cities $(2,544,400)$, followed by towns and suburbs $(2,521,600)$, and rural areas $(913,100)$. In 2013 the situation appeared to have changed radically. The number of young people residing in cities dropped dramatically $(1,917,500)$ while that of those residing in rural areas increased strongly $(1,450,700)$. On the other hand, the number of those living in towns and suburbs barely grew $(2,627,900)$. As for 2019 , the part of young people residing in cities rose slightly $(1,921,700)$, while the number of those residing in towns and suburbs $(2,580,300)$ and rural areas $(1,369,300)$ decreased. These data are consistent with those of the general population.

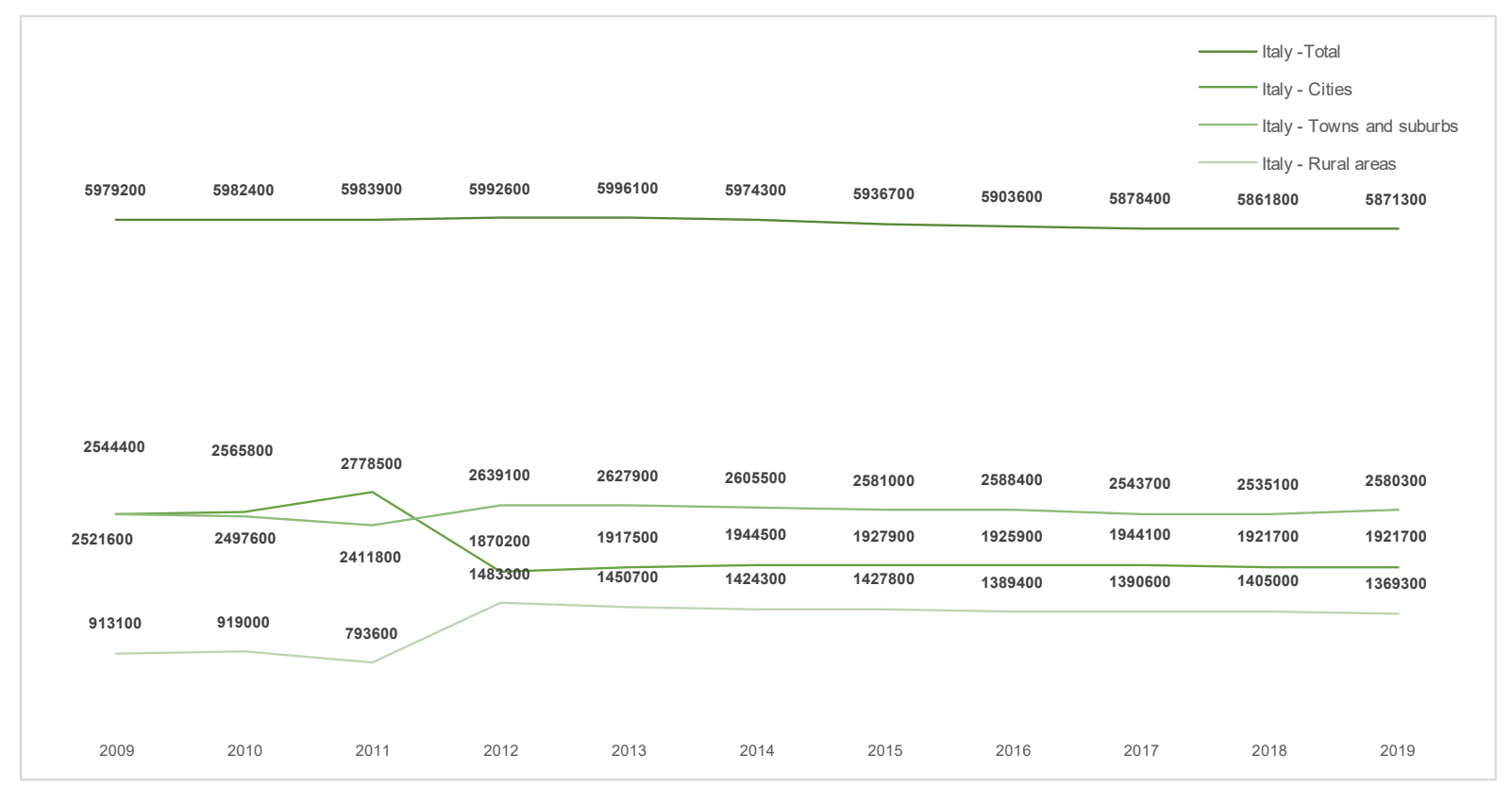

Source: Eurostat (Ifst_r_pgauwsc) - data extracted on 12.05.2020 
According to Table 2, overall, the youth population ratio in Italy has been declining between 2011 and 2019. However, the 25-29 age group seems to have a more remarkable relative change $(-5.36 \%)$ than the $15-19(-2.04 \%)$ and $20-24$ age groups $(1.96 \%)$.

Table 2. Ratio of youth population by age subgroups and absolute and relative change in Italy (2011-2015, 2015-2019 and 2011-2019)

\begin{tabular}{|c|c|c|c|c|c|c|}
\hline & 2009 & 2013 & 2019 & $\begin{array}{c}\text { Absolute change } \\
\text { 2009-2013 } \\
\text { (Relative change } \\
\text { 2009-2013) }\end{array}$ & $\begin{array}{c}\text { Absolute change } \\
\text { 2013-2009 } \\
\text { (Relative change } \\
\text { 2013-2019) }\end{array}$ & $\begin{array}{c}\text { Absolute change } \\
\text { 2009-2019 } \\
\text { (Relative change } \\
2009-2019 \text { ) }\end{array}$ \\
\hline \multicolumn{7}{|c|}{ Age groups } \\
\hline $15-19$ & $4.90 \%$ & $4.70 \%$ & $4.80 \%$ & -0.20 pp $(-4.08 \%)$ & $0,10 \mathrm{pp}(2.13 \%)$ & -0.10 pp (-2.04\%) \\
\hline $20-24$ & $5.10 \%$ & $5.10 \%$ & $5.00 \%$ & O (O) & $-0.10 \mathrm{pp}(-1.96 \%)$ & -0.10 pp $(-1.96 \%)$ \\
\hline $25-29$ & $5.60 \%$ & $5.40 \%$ & $5.30 \%$ & $-0.20 \mathrm{pp}(-3.57 \%)$ & $-0.10 p p(-1.85 \%)$ & $-0.30 p p(-5.36 \%)$ \\
\hline
\end{tabular}

Source: Eurostat: yth_demo_020 - data extracted in 13.05.20 


\section{2. Employment and Unemployment}

\section{2. 1. Youth employment}

Below is a description of young Italians' employment indexes (15-34 years) for 2009 and 2019. The data will be described considering the degree of urbanisation and the age group, as detailed in Table 3. The age groups considered are: 15-19; 20-24; 25-29; and, 30-34. The comparison between the two years will also be considered.

2009 is characterised by an overall youth employment rate of $54.60 \%$, which in cities becomes $54.10 \%$, in towns and suburbs $55.06 \%$, and in rural areas $52.80 \%$. If we analyse the various degrees of urbanisation in the different age groups, the following can be said. In cities, the $15-19$ age group's employment rate is $4.90 \%$, in the $20-24$ age group $34.3 \%$, in the 25-29 age group $60.2 \%$ and finally in the $30-34$ age group $73.00 \%$. For towns and suburbs in the $15-19$ age group, the employment rate is $5.7 \%, 39.4 \%$ for the $20-24$ age group, $62.8 \%$ for the 25-29 age group, and $72.9 \%$ for the 30-34 age group. The employment rate in rural areas is $6.9 \%$ for the $15-19$ age group, $38.0 \%$ for the $20-24$ age group, $59.4 \%$ for the $25-29$ age group, and $70.3 \%$ for the $30-34$ age group. As is to be expected, in all three degrees of urbanisation, the highest employment rate is found in the 30-34 age group, followed by 25-29, 20-24, and 15-19, respectively. The 15-19 age group sees a higher rate in rural areas (6.90\%), followed by towns and suburbs (5.70\%) and cities (4.90\%). The $20-24$ age group has higher employment rates in villages and suburbs (39.40\%), followed slightly by rural areas (38.00\%) and finally, with a more massive gap, cities (34.30\%). The $25-29$ age group also has the highest rate in towns and suburbs (62.80\%), followed by cities $(60.20 \%)$ and rural areas (59.40\%). As mentioned above, the 30-34 age group sees employment rates plus others with $73.00 \%$ in cities, $72.90 \%$ in towns and suburbs, and $70.30 \%$ in rural areas.

2019 is characterised by an overall youth employment rate of $48.70 \%, 47.50 \%$ in cities, $49.20 \%$ in towns and suburbs, and $49.60 \%$ in rural areas. If we analyse the various degrees of urbanisation in the different age groups, we find the following results. In cities, the 15-19 age group's employment rate corresponds to $2.70 \%$; in the $20-24$ age group to $27.70 \%$; in the $25-29$ age group to $53.10 \%$; and, finally in the $30-34$ age group, to $68.90 \%$. Regarding towns and suburbs, the employment rate is $4.00 \%$ in the $15-19$ age group, $34.40 \%$ in the 
20-24 age group, $58.70 \%$ in the $25-29$ age group, and $68.80 \%$ in the $30-34$ age group. The employment rate is $4.70 \%$ in rural areas concerning the $15-19$ age group, $36.90 \%$ in the $20-$ 24 age group, $56.60 \%$ in the $25-29$ age group and, $67.30 \%$ in the $30-34$ age group. As in 2009 , in 2019 the $30-34$ age group presents the highest employment rates in all the three degrees of urbanisation.

Overall, 2019 saw a 10.81\% decrease in the employment rate (with a loss of 5.90 percentage points) compared to 2009. Cities and towns and suburbs seem to be the most affected, with a decrease of $12.20 \%$ and $11.51 \%$, corresponding to an absolute reduction of 6.60 and 6.40 percentage points, respectively. Rural areas show a decrease of 3.20 percentage points, corresponding to $6.06 \%$. In conclusion, while in 2009 rural areas had the lowest employment rate (52.80\%), in 2019 it was the cities (47.5\%). 
Table 3. Youth employment (\%) and absolute and relative change in Italy by age subgroups and degree of urbanisation (2009-2013, 2013-2019, and 2009-2019)

\begin{tabular}{|c|c|c|c|c|c|c|}
\hline & 2009 & 2013 & 2019 & $\begin{array}{c}\text { Absolute change } \\
\text { 2009-2013 } \\
\text { (Relative change } \\
\text { 2009-2013) }\end{array}$ & $\begin{array}{c}\text { Absolute change } \\
\text { 2013-2009 } \\
\text { (Relative change } \\
2013-2019 \text { ) }\end{array}$ & $\begin{array}{c}\text { Absolute change } \\
\text { 2009-2019 } \\
\text { (Relative change } \\
\text { 2009-2019) }\end{array}$ \\
\hline \multicolumn{7}{|l|}{ Cities } \\
\hline \multicolumn{7}{|c|}{ Age groups } \\
\hline Overall & $54.10 \%$ & $46.50 \%$ & $47.50 \%$ & -7.60 pp (-14.05\%) & $1.00 \mathrm{pp}(2.15 \%)$ & $-6.60 \mathrm{pp}(-12.20 \%)$ \\
\hline $15-19$ & $4.90 \%$ & $1.90 \%$ & $2.70 \%$ & $-3.0 \mathrm{pp}(-61.22 \%)$ & $0.80 \mathrm{pp}(42.11 \%)$ & $-2.20 \mathrm{pp}(-44.90 \%)$ \\
\hline $20-24$ & $34.30 \%$ & $23.80 \%$ & $27.70 \%$ & $-10.50 \mathrm{pp}(-30.61 \%)$ & 3.90 pp (16.39\%) & -6.60 pp $(-19.24 \%)$ \\
\hline $25-29$ & $60.20 \%$ & $50.10 \%$ & $53.10 \%$ & -10.10 pp (-16.78\%) & $3.00 \mathrm{pp}(5.99 \%)$ & -7.10 pp (-11.79\%) \\
\hline $30-34$ & $73.00 \%$ & $65.70 \%$ & $68.90 \%$ & $-7.30 \mathrm{pp}(-10.00 \%)$ & $3.20 \mathrm{pp}(4.87 \%)$ & $-4.10 \mathrm{pp}(-5.62 \%)$ \\
\hline \multicolumn{7}{|l|}{$\begin{array}{l}\text { Towns and } \\
\text { suburbs }\end{array}$} \\
\hline \multicolumn{7}{|c|}{ Age groups } \\
\hline Overall & $55.6 \%$ & $49.30 \%$ & $49.2 \%$ & $-6.30 \mathrm{pp}(-11.33 \%)$ & $-0.10 \mathrm{pp}(-0.20 \%)$ & -6.40 pp (-11.51\%) \\
\hline $15-19$ & $5.7 \%$ & $2.90 \%$ & $4.0 \%$ & $-2.80 \mathrm{pp}(-49.12 \%)$ & 1.10 pp (37.93\%) & $-1.70 \mathrm{pp}(-29.82 \%)$ \\
\hline $20-24$ & $39.4 \%$ & $30.90 \%$ & $34.4 \%$ & $-8.50 \mathrm{pp}(-21.57 \%)$ & $3.50 \mathrm{pp}(11.33 \%)$ & $-5.00 \mathrm{pp}(-12.69 \%)$ \\
\hline $25-29$ & $62.8 \%$ & $53.80 \%$ & $58.7 \%$ & $-9.00 \mathrm{pp}(-14.33 \%)$ & $4.90 \mathrm{pp}(9.11 \%)$ & $-4.10 \mathrm{pp}(-6.53 \%)$ \\
\hline $30-34$ & $72.9 \%$ & $68.20 \%$ & $68.8 \%$ & $-4.70 \mathrm{pp}(-6.45 \%)$ & $0.60 \mathrm{pp}(0.88 \%)$ & $-4.10 \mathrm{pp}(-5.62 \%)$ \\
\hline \multicolumn{7}{|l|}{ Rural areas } \\
\hline \multicolumn{7}{|l|}{ Age groups } \\
\hline Overall & $52.8 \%$ & $48.60 \%$ & $49.6 \%$ & -4.20 pp $(-7.95 \%)$ & $1.00 \mathrm{pp}(2.06 \%)$ & -3.20 pp $(-6.06 \%)$ \\
\hline $15-19$ & $6.9 \%$ & $3.40 \%$ & $4.7 \%$ & $-3.50 \mathrm{pp}(-50.72 \%)$ & $1.30 \mathrm{pp}(38.24 \%)$ & $-2.20 \mathrm{pp}(-31.88 \%)$ \\
\hline $20-24$ & $38.0 \%$ & $31.50 \%$ & $36.9 \%$ & -6.50 pp (-17.11\%) & 5.40 pp (17.14\%) & -1.10 pp (-2.89\%) \\
\hline $25-29$ & $59.4 \%$ & $54.10 \%$ & $56.6 \%$ & $-5.30 \mathrm{pp}(-8.92 \%)$ & $2.50 \mathrm{pp}(4.62 \%)$ & $-2.80 \mathrm{pp}(-4.71 \%)$ \\
\hline $30-34$ & $70.3 \%$ & $65.40 \%$ & $67.3 \%$ & $-4.90 \mathrm{pp}(-6.97 \%)$ & $1.90 \mathrm{pp}(2.91 \%)$ & $-3.00 \mathrm{pp}(-4.27 \%)$ \\
\hline
\end{tabular}

Source: Eurostat (Ifst_r_ergrau) - data extracted on 29.04.2020 
The chart below compares the trend in youth employment by degree of urbanisation from 2009 to 2019. As explained above, from 2009 to 2019 there was a decrease in the level of youth employment. The chart clearly shows a substantial decrease, reaching its lowest level in 2014 for cities (45.80\%) as well as towns and suburbs (47.90\%) and in 2015 for rural areas (47.40\%). As a result of this peak, rates seem to be recovering, although much more slowly. In conclusion, cities have been most affected over time, both in terms of numbers and intensity.

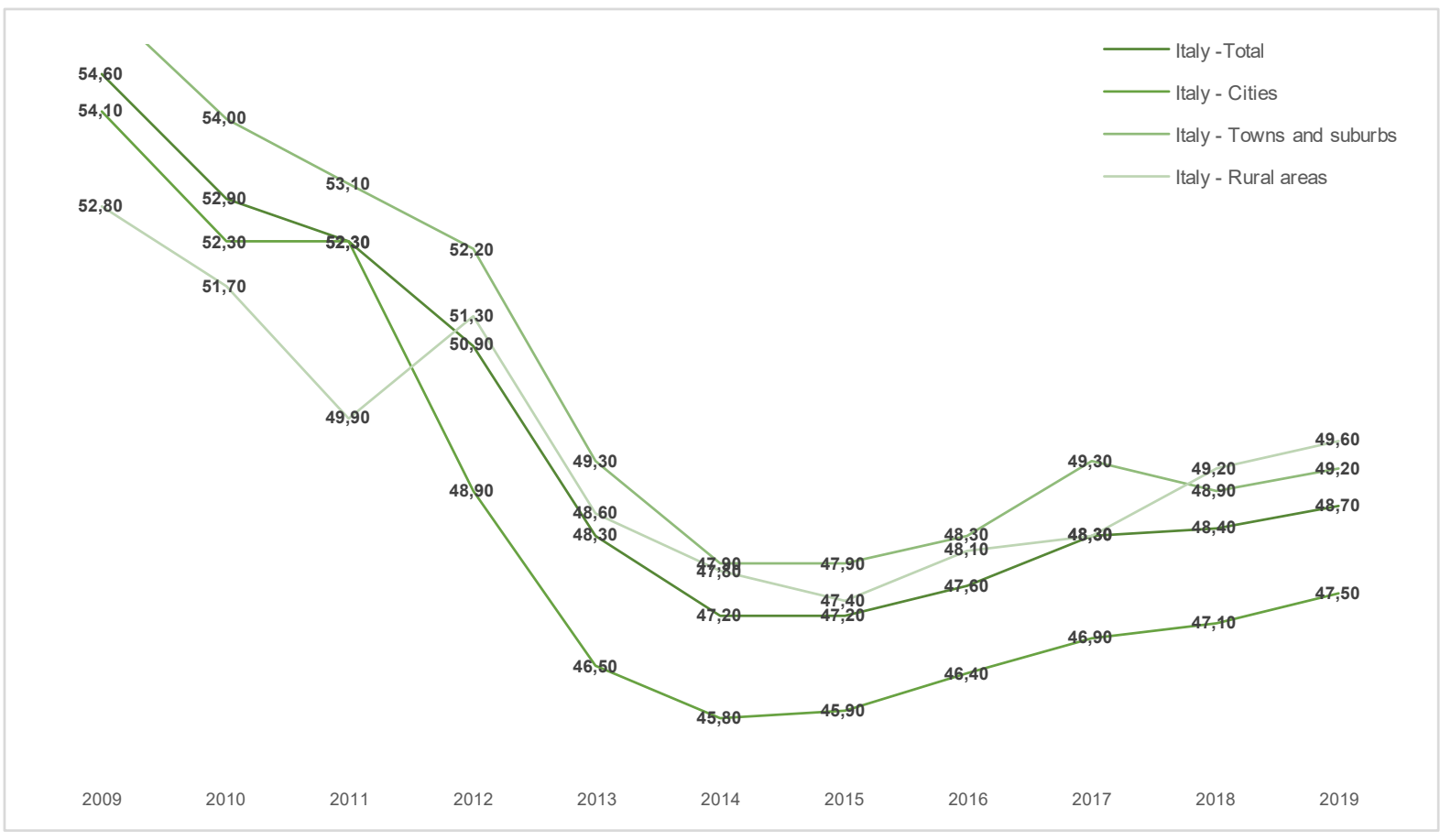

Source: Eurostat (Ifst_r_ergrau) - data extracted on 29.04.2020 


\section{2. 2. Youth unemployment}

This section describes the ratio of youth unemployment in 2009, 2013 and 2019, taking into account both the degree of urbanisation and different age groups. Respective comparisons are also considered.

The overall unemployment rate in 2009 was $11.5 \%$. More specifically, as can be seen from Table 4, youth unemployment is higher in rural areas (12.20\%) followed by cities $(11.80 \%)$ and towns and suburbs (11.00\%). Taking cities into consideration, the age group that presents the highest unemployment rate is the 15-19 age group that presents a percentage of unemployed equal to $41.60 \%$ of the considered population, followed by $20-24$ with a rate of $25.00 \%$, 25-20 with $13.60 \%$ and finally the $30-34$ age group with $8.60 \%$. Furthermore, in towns and suburbs we see that the 15-19 age group has the highest levels of unemployment (39.00\%), followed by the 20-25 group (20.60\%), and then the $25-29$ group (12.80\%) and the $30-34$ group (8.40\%). Rural areas show a similar trend, where $37.90 \%$ of young people between 15 and 19 years old are unemployed. We also find the 20-25 group with an unemployment level of $22.30 \%$, the $25-29$ group with $13.90 \%$, and finally the $30-34$ group with $9.10 \%$.

2013 is characterised by an overall unemployment rate of $18.60 \%$. Unemployment is higher in cities where it reaches $19.90 \%$, followed by rural areas with $18.9 \%$ and towns and suburbs with $17.60 \%$.

Concerning cities, the age group with the highest unemployment rate is 15-19 (68.90\%), followed by $20-24$ (41.10\%), 25-29 (24.20\%) and finally 30-34 (16.00\%). The towns and suburbs also have the $15-19$ age group as that with the highest rate $(61.40 \%)$, followed by 20-24 (34.90\%), 25-29 (21.20\%) and finally 30-34 (16.00\%). Similar percentages of unemployment are also found in rural areas, where the 15-19 group reaches $61.80 \%$, followed by $34.30 \%$ in the $20-24$ group, $21.50 \%$ in the $25-29$ group and finally $14.80 \%$ in the $30-34$ group. This data clearly shows a significant increase in unemployment compared to 2009 . If we consider the percentage points, the 15-19 age group is the most affected, with an increase of 27.30 percentage points (absolute change) in cities, 22.40 percentage points (absolute change) in towns and suburbs and 23.90 percentage points (absolute change) in rural areas. The overall increase was significant in all three degrees of urbanisation where 
in cities the number of unemployed increased by $68.64 \%$, followed by towns and suburbs which saw an increase of $60.00 \%$ and finally rural areas with an increase of $54.92 \%$. As can be seen, it is the cities that have the highest change and, in particular, the attention is focused on the groups $25-29$ and $30-34$ where there is an increase of $77.94 \%$ and $86.05 \%$ (relative change) respectively, corresponding to an increase of 10.60 and 7.40 percentage points (absolute change). This means that, in cities, the number of unemployed people between 25 and 34 years old has almost doubled in just 4 years.

With regards to 2019 , it shows a total unemployment rate of $15.60 \%$. Unemployment is higher in cities where it reaches $17.10 \%$ of the youth population, followed by rural areas with $14.90 \%$ and towns and suburbs with $14.80 \%$. Taking cities into account, the age group with the highest unemployment rate is $15-19$ (56.00\%), followed by $20-24$ (30.30\%), 25-29 (20.80\%) and finally $30-34$ (13.10\%). Towns and suburbs also see the $15-19$ age group as that with the highest rate (47.00\%), followed by $20-24$ (25.00\%), 25-29 (15.90\%) and finally $30-34$ (11.80\%). As far as rural areas are concerned, the age range $15-19$ reaches $40.40 \%$, followed by $23.90 \%$ in the $20-24$ range, $16.30 \%$ in the $25-29$ range and finally $12.90 \%$ in the 30-34 range. Compared to 2013, 2019 shows a generalised decrease in youth unemployment. However, as shown in Table 4, the pre-2013 levels do not seem to have been reached. The values are still higher than those of 2009: in cities there is an overall relative increase of $44.92 \%$, in towns and suburbs of $34.55 \%$ and in rural areas $22.13 \%$, corresponding to an increase of 5.30, 3.80 and 2.70 percentage points respectively (absolute change). It can be seen that cities manifests the biggest increase. 


\begin{tabular}{|c|c|c|c|c|c|c|}
\hline & 2009 & 2013 & 2019 & $\begin{array}{c}\text { Absolute change } \\
\text { 2009-2013 } \\
\text { (Relative change } \\
\text { 2009-2013) }\end{array}$ & $\begin{array}{c}\text { Absolute change } \\
\text { 2013-2009 } \\
\text { (Relative change } \\
\text { 2013-2019) }\end{array}$ & $\begin{array}{c}\text { Absolute change } \\
\text { 2009-2019 } \\
\text { (Relative change } \\
\text { 2009-2019) }\end{array}$ \\
\hline \multicolumn{7}{|l|}{ Cities } \\
\hline \multicolumn{7}{|c|}{ Age groups } \\
\hline Overall & $11.80 \%$ & $19.90 \%$ & $17.10 \%$ & 8.10 pp (68.64\%) & $-2.80 \mathrm{pp}(-14.07 \%)$ & 5.30 pp (44.92\%) \\
\hline $15-19$ & $41.60 \%$ & $68.90 \%$ & $56.00 \%$ & $27.30 \mathrm{pp}(65.63 \%)$ & $-12.90 \mathrm{pp}(-18.72 \%)$ & $14.40 \mathrm{pp}(34.62 \%)$ \\
\hline $20-24$ & $25.00 \%$ & $41.10 \%$ & $30.30 \%$ & $16.10 \mathrm{pp}(64.40 \%)$ & $-10.80 \mathrm{pp}(-26.28 \%)$ & $5.30 \mathrm{pp}(21.20 \%)$ \\
\hline $25-29$ & $13.60 \%$ & $24.20 \%$ & $20.80 \%$ & 10.60 pp (77.94\%) & $-3.40 \mathrm{pp}(-14.05 \%)$ & 7.20 pp (52.94\%) \\
\hline $30-34$ & $8.60 \%$ & $16.00 \%$ & $13.10 \%$ & 7.40 pp (86.05\%) & $-2.90 \mathrm{pp}(-18.13 \%)$ & $4.50 \mathrm{pp}(52.33 \%)$ \\
\hline \multicolumn{7}{|c|}{$\begin{array}{l}\text { Towns and } \\
\text { suburbs }\end{array}$} \\
\hline \multicolumn{7}{|c|}{ Age groups } \\
\hline Overall & $11.00 \%$ & $17.60 \%$ & $14.80 \%$ & $6.60 \mathrm{pp}(60.00 \%)$ & $-2.80 \mathrm{pp}(-15.91 \%)$ & 3.80 pp (34.55\%) \\
\hline $15-19$ & $39.00 \%$ & $61.40 \%$ & $47.00 \%$ & $22.40 \mathrm{pp}(57.44 \%)$ & $-14.40 \mathrm{pp}(-23.45 \%)$ & 8.00 pp (20.51\%) \\
\hline $20-24$ & $20.60 \%$ & $34.90 \%$ & $25.00 \%$ & $14.30 \mathrm{pp}(69.42 \%)$ & $-9.90 \mathrm{pp}(-28.37 \%)$ & $4.40 \mathrm{pp}(21.36 \%)$ \\
\hline $25-29$ & $12.80 \%$ & $21.20 \%$ & $15.90 \%$ & $8.40 \mathrm{pp}(65.63 \%)$ & $-5.30 p p(-25.00 \%)$ & 3.10 pp (24.22\%) \\
\hline $30-34$ & $8.40 \%$ & $12.70 \%$ & $11.80 \%$ & $4.30 \mathrm{pp}(51.19 \%)$ & $-0.90 \mathrm{pp}(-7.09 \%)$ & $3.40 \mathrm{pp}(40.48 \%)$ \\
\hline \multicolumn{7}{|c|}{ Rural areas } \\
\hline \multicolumn{7}{|c|}{ Age groups } \\
\hline Overall & $12.20 \%$ & $18.90 \%$ & $14.90 \%$ & 6.70 pp (54.92\%) & $-4.00 \mathrm{pp}(-21.16 \%)$ & $2.70 \mathrm{pp}(22.13 \%)$ \\
\hline $15-19$ & $37.90 \%$ & $61.80 \%$ & $40.40 \%$ & $23.90 \mathrm{pp}(63.06 \%)$ & $-21.40 \mathrm{pp}(-34.63 \%)$ & $2.50 \mathrm{pp}(6.60 \%)$ \\
\hline $20-24$ & $22.30 \%$ & $34.30 \%$ & $23.90 \%$ & $12.00 \mathrm{pp}(53.81 \%)$ & $-10.40 \mathrm{pp}(-30.32 \%)$ & $1.60 \mathrm{pp}(7.17 \%)$ \\
\hline $25-29$ & $13.90 \%$ & $21.50 \%$ & $16.30 \%$ & 7.60 pp (54.68\%) & $-5.20 \mathrm{pp}(-24.19 \%)$ & $2.40 \mathrm{pp}(17.27 \%)$ \\
\hline $30-34$ & $9.10 \%$ & $14.80 \%$ & $12.90 \%$ & $5.70 \mathrm{pp}(62.64 \%)$ & $-1.90 \mathrm{pp}(-12.84 \%)$ & $3.80 \mathrm{pp}(41.76 \%)$ \\
\hline
\end{tabular}

Source: Eurostat (Ifst_r_ergrau) - data extracted on 29.04.2020 
The chart illustrated below shows the development of the youth unemployment rate from 2009 until 2019. It is interesting to note that from 2011 to 2012 there is a steep increase in youth unemployment, which reached its peak in 2014. In the following years, we can see the beginning of a very gradual decline. All three degrees of urbanisation show the same trend but, as described above, cities reach the highest levels of unemployment and see a slower decrease compared to towns and suburbs and rural areas.

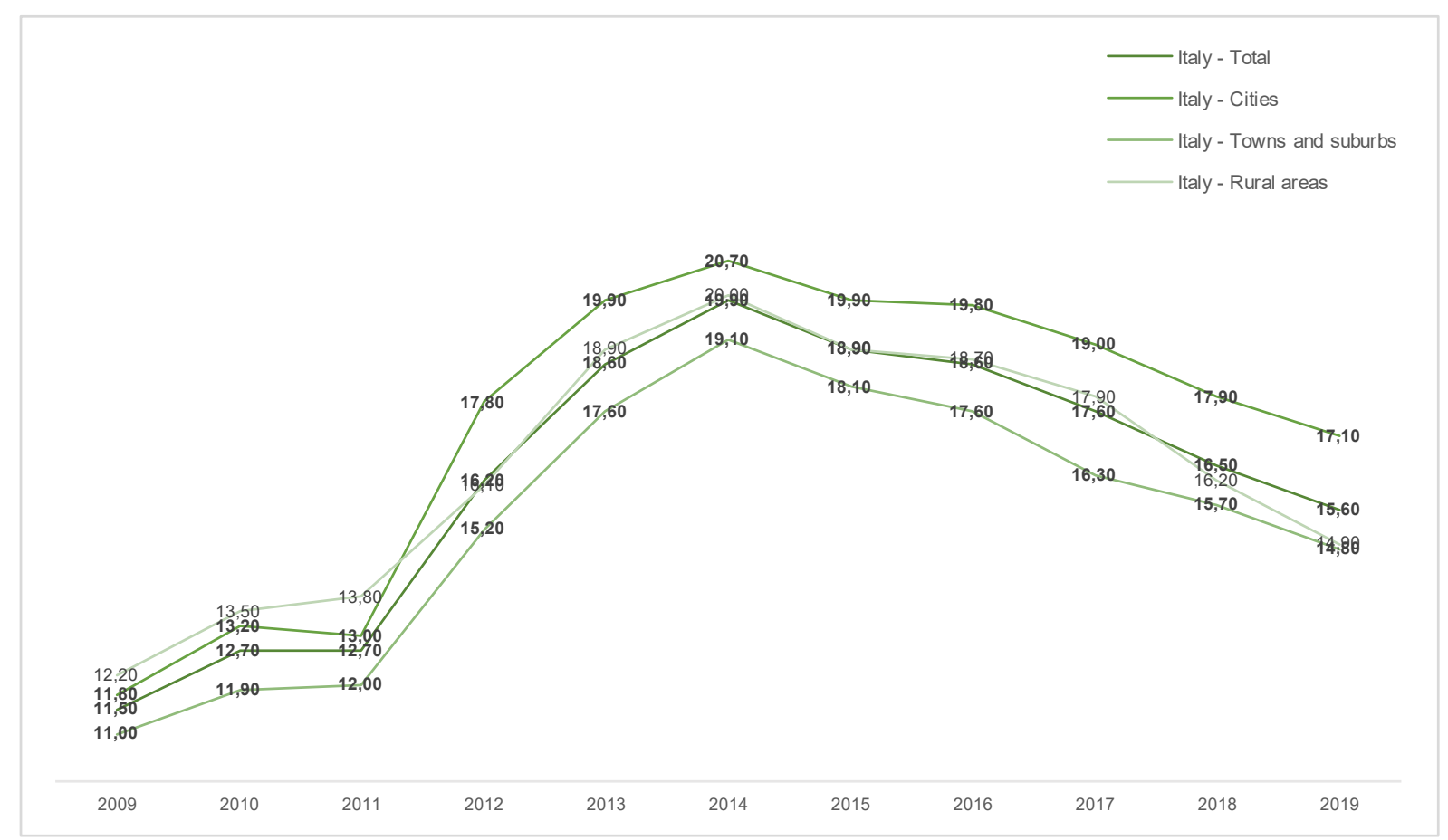

Source: Eurostat (Ifst_r_ergrau) - data extracted on 29.04.2020 


\section{3. Education}

\section{3. 1. Young people by educational attainment level}

This paragraph describes the Italian youth population when considering the level of education and the degree of urbanisation. Data from the years 2009, 2013 and 2019 are analysed. To carry out these analyses, young people between 15 and 24 years of age have been taken into consideration.

With regards to cities, in $200955.20 \%$ of young people were declared as having a 0-2 level qualification. In 2013 there is a decrease of $5.62 \%$, with a loss of 3.10 percentage points, reaching $52.10 \%$. In 2019 , this figure continued to fall, losing a further $2.30 \%$ (relative change), corresponding to a 1.20 percentage points (absolute change), and reaching $50.90 \%$ of young people with a 0-2 level of education. Therefore, the overall change between 2009 and 2019 consists of a loss of $7.79 \%$ (relative change), corresponding to a loss of 4.30 percentage points (absolute change).

The number of young people with an education level of $3-4$ in 2009 is $41.30 \%$, rising to $43.40 \%$ in 2013 and then falling again to $43.00 \%$ in 2019 . This represents an increase of $5.08 \%$ (2.10pp absolute change) between 2009 and 2013; a decrease of $0.92 \%$ (0.4pp absolute change) between 2013 and 2019; and, an overall increase in 2019 of 4.12\% (1.7pp absolute change) compared to 2009. 3.5\% of the youth population in 2009 had an education level of $5-8$. It rose to $4.50 \%$ in 2013 and $6.10 \%$ in 2019 , showing an overall increase of $74.29 \%$ (2.6pp absolute change).

On the other hand, in towns and suburbs, $53.80 \%$ of youths between 15 and 24 years of age have a O-2 level of education in 2009. This ratio drops to $53.50 \%$ in 2013 and it drops again to $50.70 \%$ in 2019 . From 2009 to 2019 , there is $5.82 \%$ loss overall (3.10pp absolute change). Those with a level of education $3-4$ are the $42.70 \%$ of young population in 2009 , rising to $44.00 \%$ in 2013 and to $44.20 \%$ in 2019, increasing by 1.50 pp (absolute change) which corresponds to $3.51 \%$ (relative change). An education level of $5-8$ was possessed by $3.50 \%$ of youths in 2009 . The ratio remains constant in 2013 until it increases to $45.71 \%$ (relative change) in 2019. 
The situation in rural areas is quite similar. $54.8 \%$ of young people claim to have a 0-2 level of education in 2009. The number tends to decrease in the following years, reaching $51.50 \%$ in 2013 , and finally $50.70 \%$ in 2019 . In 2019 , therefore, the total number is 4.10 pp (absolute change) lower than in 2009 , and corresponding to a decrease of $7.48 \%$ (relative change). Regarding the level of education $3-4,42.40 \%$ of young people had it in 2009 , reaching $45.50 \%$ in 2013 and finally $45.30 \%$ in 2019 . Only $2.80 \%$ claimed to have an education level of $5-8$ in 2009 . This figure increased to $3.10 \%$ in 2013 and $4.00 \%$ in 2019 , representing an overall increase of $42.86 \%$ (relative change), which corresponds to an increase of 1.20pp (absolute change).

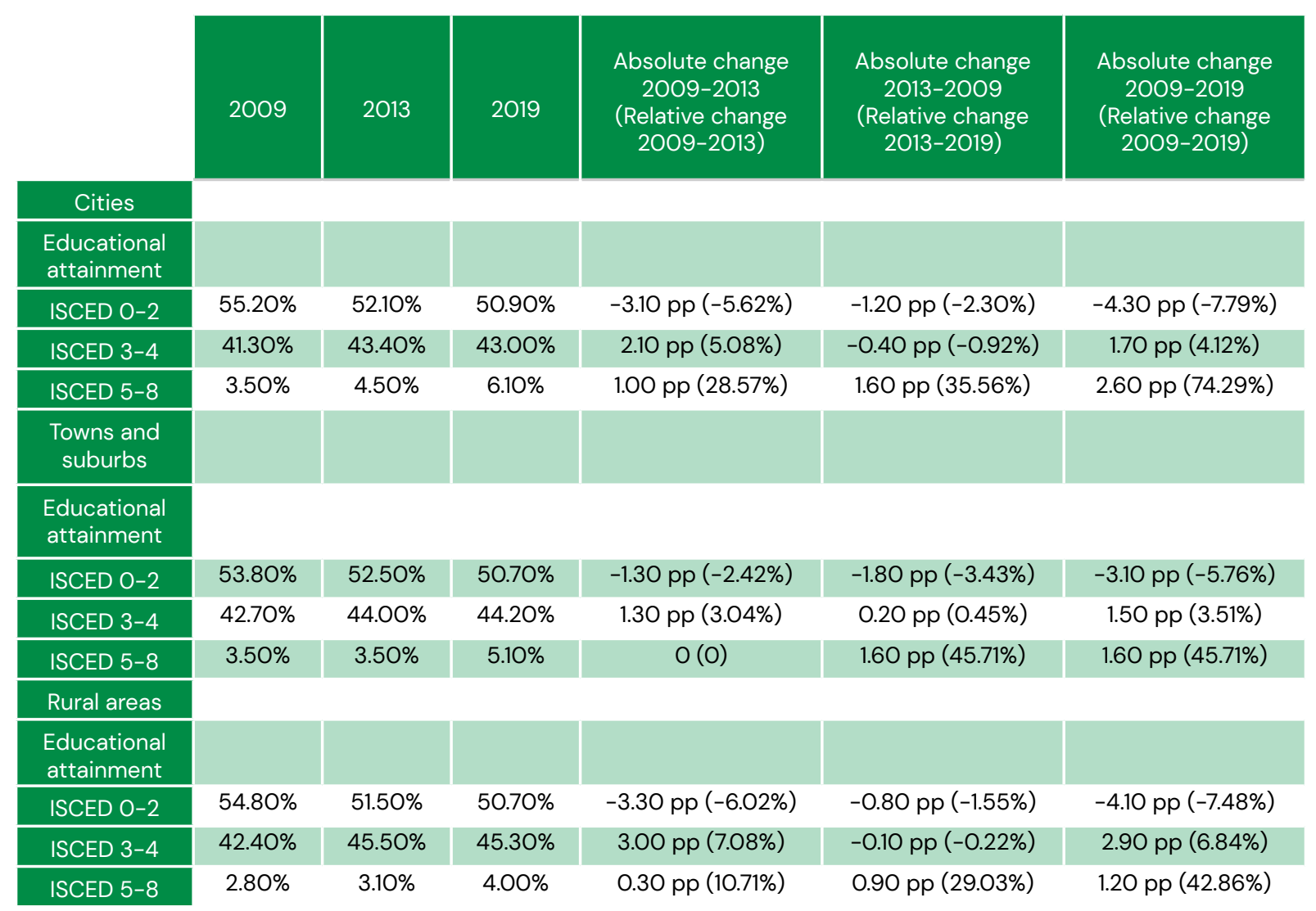

Source: Eurostat (edat_lfse_9913) - data extracted in 29.04.2020 
The charts below show the trend in the education levels of young Italians from 2009 to 2019. In general, it can be said that the percentages concerning the 0-2 education level tends to decrease. Conversely, concerning education levels 5-8, it seems to increase with the passing of the years, while those with levels 3-4, after a strong increase until 2012, subsequently remain rather constant. The situation does not seem to change much if different levels of urbanisation are taken into account.

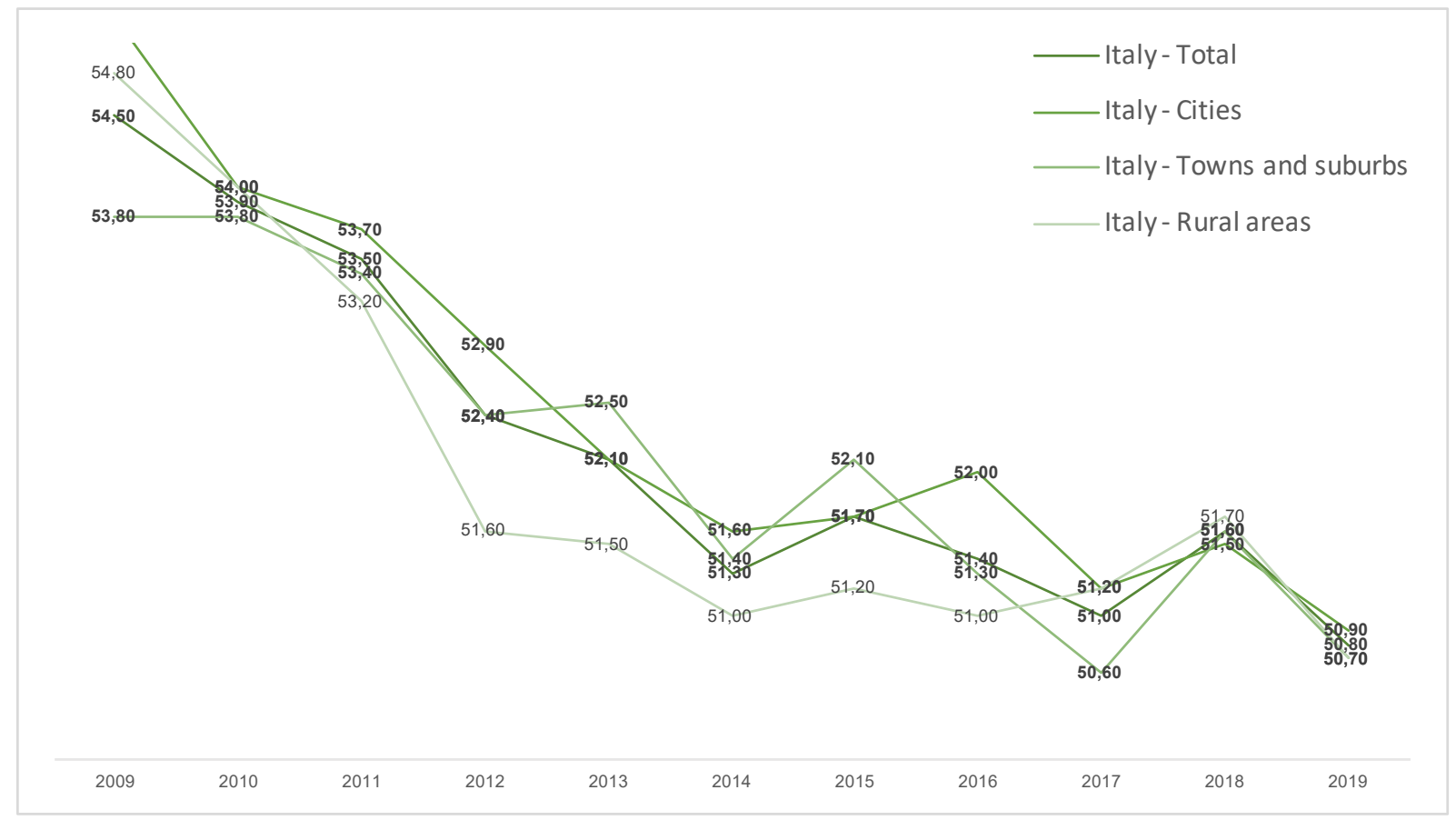

Source: Eurostat (edat_lfse_9913) - data extracted in 29.04.2020 
Chart 5. Italian population, aged 15-24, by ISCED level 3-4 (\%) and degree of urbanisation.

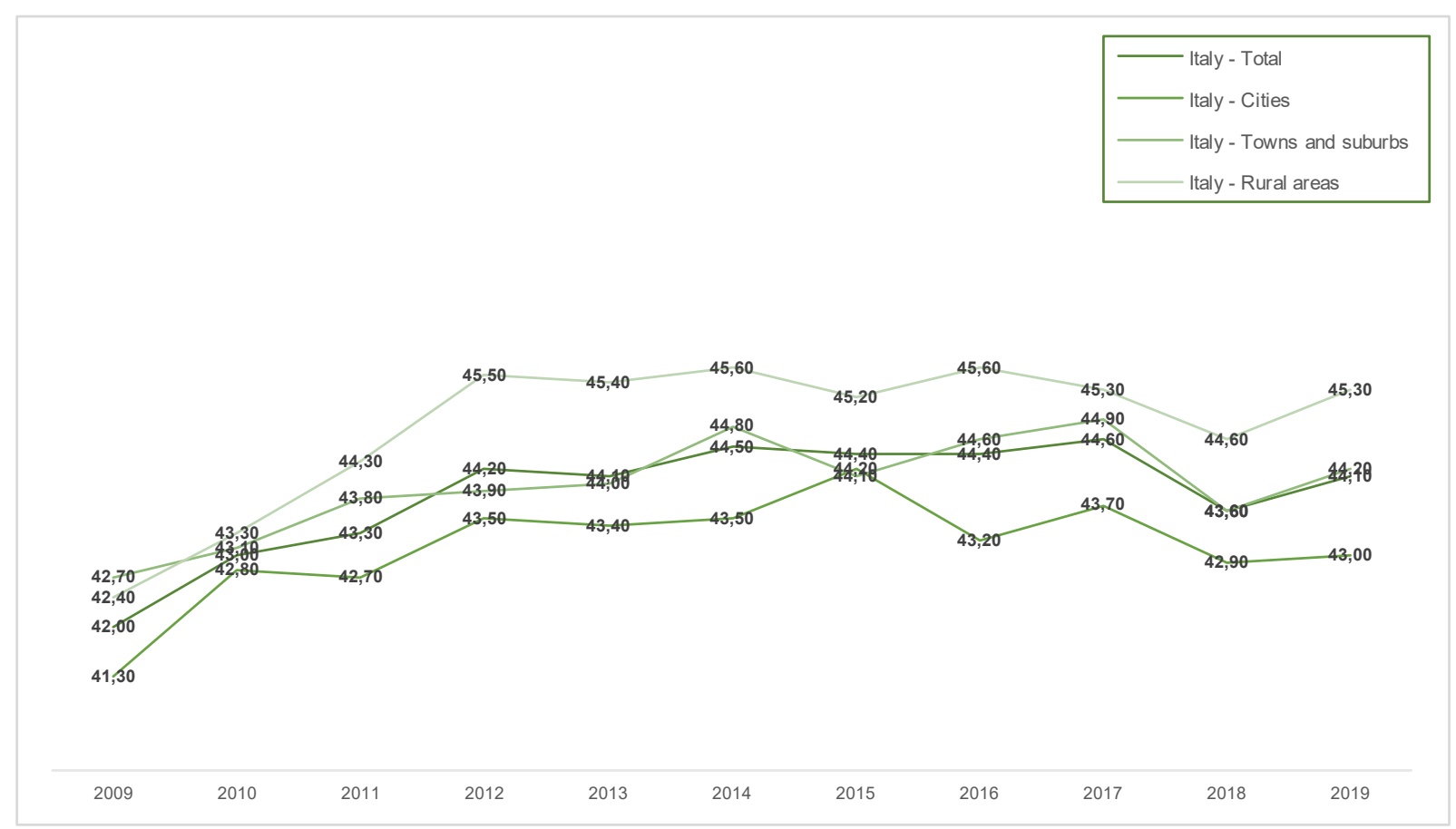

Source: Eurostat (edat_lfse_9913) - data extracted in 29.04.2020 


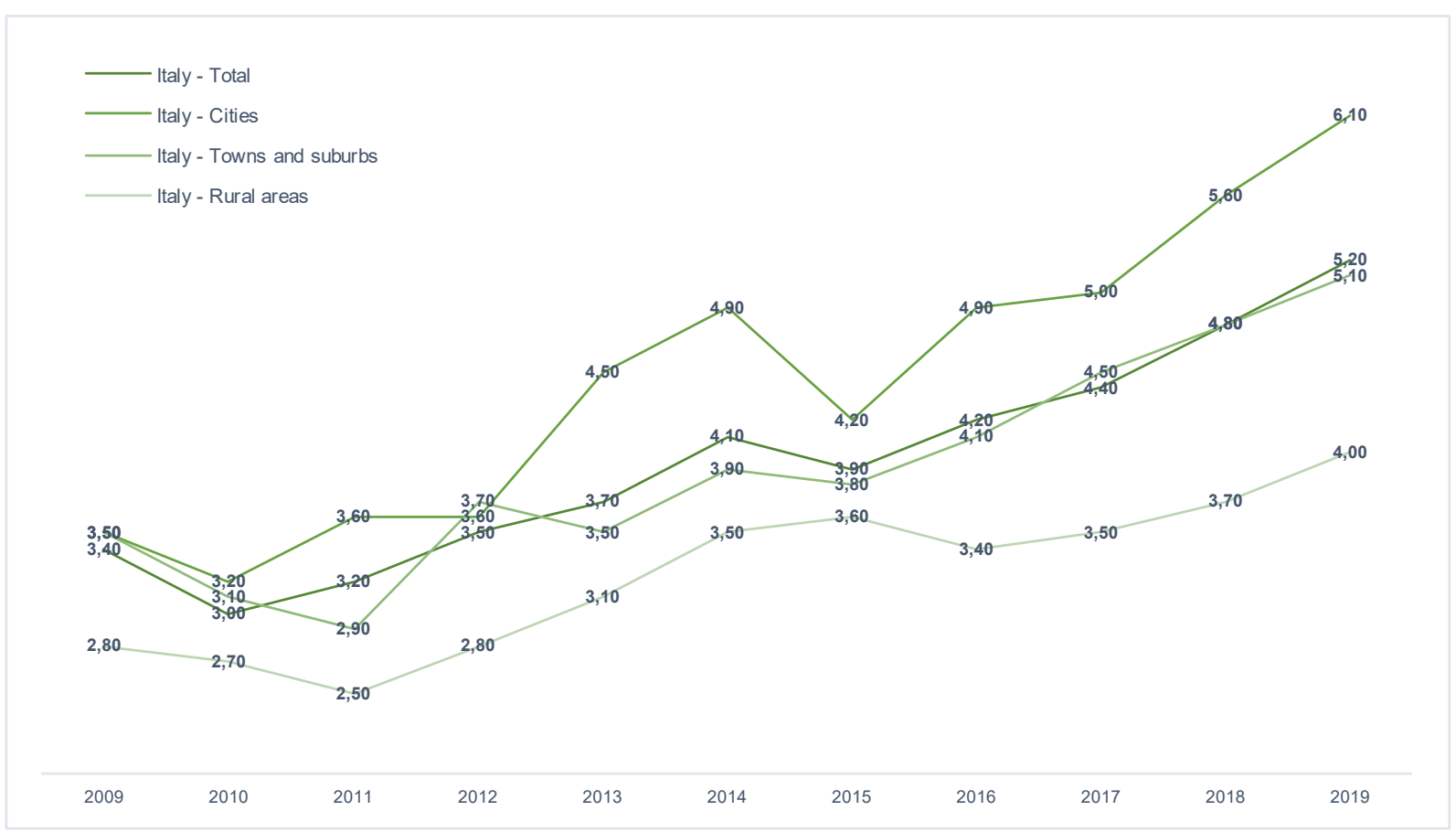

Source: Eurostat (edat_Ifse_9913) - data extracted in 29.04.2020 


\section{3. 2. Early school leavers}

In the following paragraph, the levels of school drop-out of young Italians between 18 and 24 years old are analysed, comparing related different degrees of urbanisation. Considering the context of cities, those who dropped out of school early total $18.90 \%$ of young Italians in $2009,16.70 \%$ in 2013 and $13.50 \%$ in 2019 . As Table 6 shows, from 2009 to 2019 there was a total loss of 5.40pp (absolute change), corresponding to a decrease of $28.57 \%$. The situation is similar for the towns and suburbs, where $18.70 \%$ of young people dropped out of school in 2009 , falling to $16.70 \%$ in 2013 and further to $12.90 \%$ in 2019 , with an overall decrease of $5.80 p p$ (absolute change) and $31.04 \%$ (relative change). In rural areas the rate was $20.60 \%$ in 2009 , decreasing to $17.10 \%$ in 2013 and finally reaching $14.60 \%$ in 2019 . This represents a relative decrease of $29.13 \%$ from 2009 to 2019 (absolute change: 6.00pp).

In conclusion, it can be said that the numbers of early school leavers seems to be slightly higher in rural areas than in cities and towns and suburbs, yet data between the three degrees of urbanisation seems to converge over time.

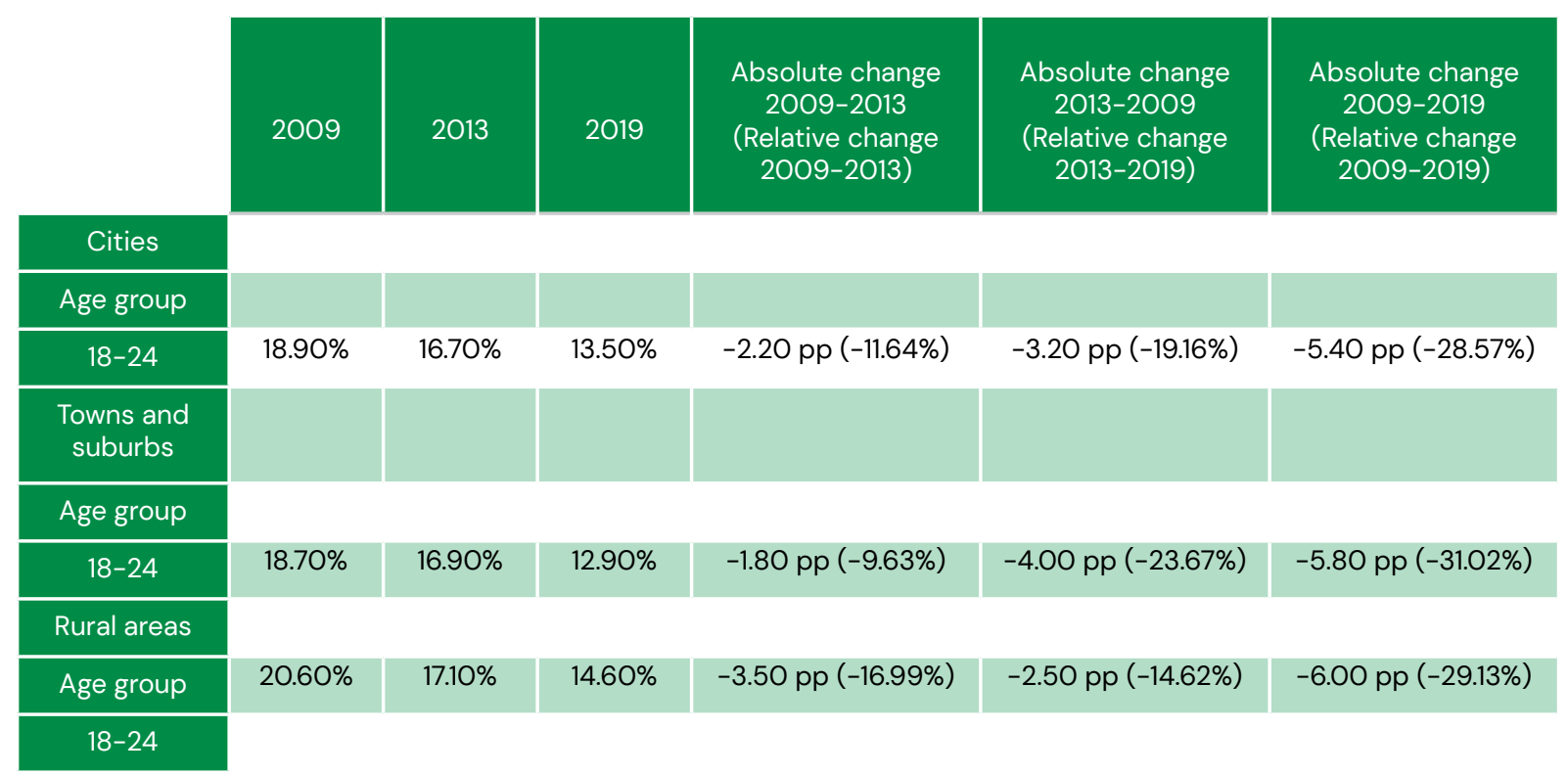

Source: Eurostat: yth_demo_020 - data extracted in 13.05.20

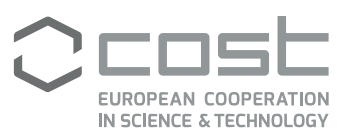


The chart below shows the trend in school drop-out rates by degree of urbanisation from 2009 to 2019, taking into account young Italians aged 18 to 24. In general, it can be said that the trend has a decreasing tendency. The differences between degrees of urbanisation do not seem to have particularly different trends.

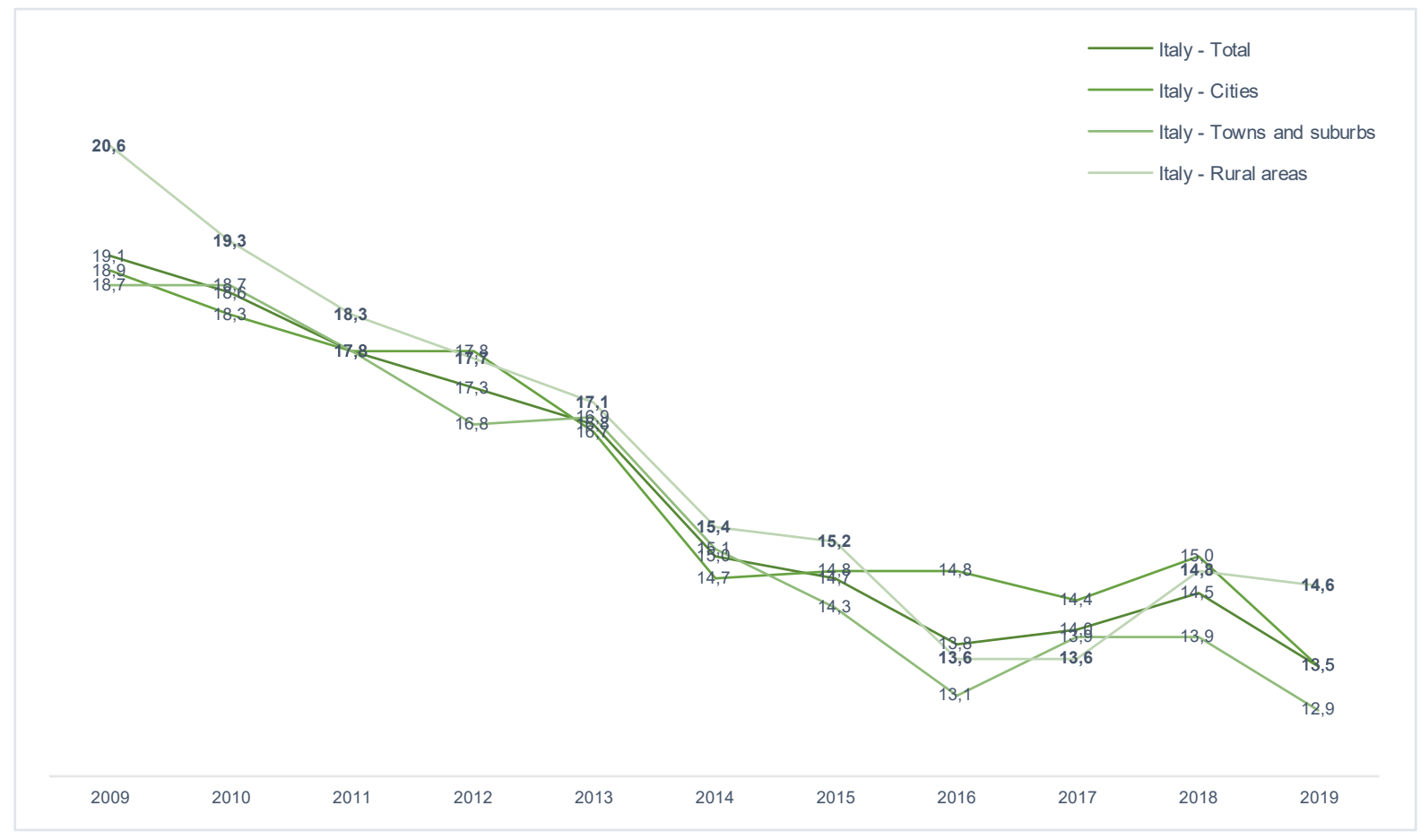

Source: Eurostat (edat_Ifse_30) - data extracted in 20.04.2020 


\section{4. NEET}

\section{4. 1. NEET rate}

This paragraph aims to analyse the percentages of NEETs within the Italian youth population, considering the differences in degree of urbanisation levels. The years considered for these analyses are as follows: 2009, 2013 and 2019.

In 2009, the percentage of NEETs is higher in rural areas (23.20\%), followed by cities (21.8\%) and towns and suburbs (21.40\%). Analysing rural areas in particular, the age group with the highest percentage of NEETs is $25-29$ with a total of $27.10 \%$, followed by $30-34$ with $26.90 \%, 20-24$ with $25.90 \%$ and finally $15-19$ with $11.80 \%$. Also, in cities the age group with the highest percentage is $25-29$ with $25.30 \%$ of NEETs, followed by $20-24$ and $30-34$ both with $24.50 \%$ and finally $15-19$ with $11.10 \%$. There is a similar trend in towns and suburbs where NEET's in the $25-29$ years range are $25.10 \%$, followed by those aged $30-34$ with $24.50 \%$, $20-24$ with $23.40 \%$ and finally 15 and 19 with $10.20 \%$ of NEETs.

In 2013 the highest percentage of NEETs is found in rural areas (28.20\%), followed by cities (27.40\%) and towns and suburbs (26.50\%). An analysis of the different age groups in rural areas shows that, as in 2009, young people between 25 and 29 years old have the highest percentage with a value of $32.80 \%$, followed by the $20-24$ age group with $32.70 \%$, the $30-$ 34 age group with $32.00 \%$ and finally the $15-19$ age group with $12.60 \%$. The trend in cities is very similar, with the percentage of NEETs between 25 and 29 years of age at $33.60 \%$, followed by $31.30 \%$ for those between 20 and 24 years of age and $31.00 \%$ for those between 30 and 34. Again, the 15-19 age group has the lowest percentage (11.40\%). Regarding the towns and suburbs, young people between 25 and 29 years old have the highest percentage of NEETs, at $32.60 \%$. Additionally, $31.90 \%$ of young people aged 20 and 24 are NEETs, with $28.80 \%$ for those aged 30 and 34 and finally $11.20 \%$ for those aged $15-19$.

2019 also presents the highest value in rural areas (24.80\%), followed by cities $(24.00 \%)$ and towns and suburbs (23.10\%). If we consider the different age groups in rural areas, the highest percentage (30.00\%) is found in the $25-29$ age group, followed by the $30-34$ age 
group (29.80\%), the $20-24$ age group (26.40\%) and finally the $15-19$ age group (11.30\%). Regarding cities, we find a $30.90 \%$ NEETs percentage among young people aged 25-29, $26.80 \%$ among those aged $30-34,25.70$ among those aged $20-24$ and $11.00 \%$ among those aged 15-19. In line with the previous conditions, towns and suburbs have $28.70 \%$ of NEETs in the $25-29$ age group, $28.20 \%$ among young people in the 30-34 year old group, $24.30 \%$ among the $20-24$ year old group and $10.30 \%$ among $15-19$ year old group.

Overall, as exemplified in Table 7, there has been an increase in NEET percentages between 2009 and 2013 (relative change: $25.69 \%$ in cities, $23.83 \%$ in towns and suburbs and $21.55 \%$ in rural areas). Conversely, from 2013 to 2019 , there has been a $12.41 \%$ decrease in cities, $12.83 \%$ in towns and suburbs, and $12.06 \%$ in rural areas (relative change). Nevertheless, this increase is not sufficient to bring the values back to 2009 levels. Differences between 2009 and 2019 remain, although less so than in 2013. 


\begin{tabular}{|c|c|c|c|c|c|c|}
\hline & 2009 & 2013 & 2019 & $\begin{array}{c}\text { Absolute change } \\
\text { 2009-2013 } \\
\text { (Relative change } \\
2009-2013 \text { ) }\end{array}$ & $\begin{array}{c}\text { Absolute change } \\
\text { 2013-2009 } \\
\text { (Relative change } \\
\text { 2013-2019) }\end{array}$ & $\begin{array}{c}\text { Absolute change } \\
\text { 2009-2019 } \\
\text { (Relative change } \\
\text { 2009-2019) }\end{array}$ \\
\hline \multicolumn{7}{|l|}{ Cities } \\
\hline \multicolumn{7}{|l|}{ Age groups } \\
\hline Overall & $21.80 \%$ & $27.40 \%$ & $24.00 \%$ & $5.60 \mathrm{pp}(25.69 \%)$ & $-3.40 \mathrm{pp}(-12.41 \%)$ & $2.20 \mathrm{pp}(10.09 \%)$ \\
\hline $15-19$ & $11.10 \%$ & $11.40 \%$ & $11.00 \%$ & $0.30 \mathrm{pp}(2.70 \%)$ & $-0.40 \mathrm{pp}(-3.51 \%)$ & $-0.10 \mathrm{pp}(-0.90 \%)$ \\
\hline $20-24$ & $24.50 \%$ & $31.30 \%$ & $25.70 \%$ & 6.80 pp (27.76\%) & $-5.60 \mathrm{pp}(-17.89 \%)$ & $1.20 \mathrm{pp}(4.90 \%)$ \\
\hline $25-29$ & $25.30 \%$ & $33.60 \%$ & $30.90 \%$ & $8.30 \mathrm{pp}(32.81 \%)$ & $-2.70 \mathrm{pp}(-8.04 \%)$ & $5.60 \mathrm{pp}(22.13 \%)$ \\
\hline $30-34$ & $24.50 \%$ & $31.00 \%$ & $26.80 \%$ & 6.50 pp (26.53\%) & -4.20 pp (-13.55\%) & $2.30 \mathrm{pp}(9.39 \%)$ \\
\hline \multicolumn{7}{|l|}{$\begin{array}{l}\text { Towns and } \\
\text { suburbs }\end{array}$} \\
\hline \multicolumn{7}{|l|}{ Age groups } \\
\hline Overall & $21.40 \%$ & $26.50 \%$ & $23.10 \%$ & 5.10 pp (23.83\%) & $-3.40 \mathrm{pp}(-12.83 \%)$ & $1.70 \mathrm{pp}(7.94 \%)$ \\
\hline $15-19$ & $10.20 \%$ & $11.20 \%$ & $10.20 \%$ & 1.00 pp (9.80\%) & -1.00 pp (-8.93\%) & $\mathrm{O}(0)$ \\
\hline $20-24$ & $23.40 \%$ & $31.90 \%$ & $24.30 \%$ & $8.50 \mathrm{pp}(36.32 \%)$ & $-7.60 \mathrm{pp}(-23.82 \%)$ & $0.90 \mathrm{pp}(3.85 \%)$ \\
\hline $25-29$ & $25.10 \%$ & $32.60 \%$ & $28.70 \%$ & 7.50 pp (29.88\%) & $-3.90 \mathrm{pp}(-11.96 \%)$ & $3.60 \mathrm{pp}(14.34 \%)$ \\
\hline $30-34$ & $24.50 \%$ & $28.80 \%$ & $28.20 \%$ & 4.30 pp (17.55\%) & $-0.60 \mathrm{pp}(-2.08 \%)$ & 3.70 pp (15.10\%) \\
\hline \multicolumn{7}{|l|}{ Rural areas } \\
\hline \multicolumn{7}{|l|}{ Age groups } \\
\hline Overall & $23.20 \%$ & $28.20 \%$ & $24.80 \%$ & 5.00 pp (21.55\%) & $-3.40 \mathrm{pp}(-12.06 \%)$ & 1.60 pp (6.90\%) \\
\hline $15-19$ & $11.80 \%$ & $12.60 \%$ & $11.30 \%$ & 0.80 pp (6.78\%) & $-1.30 \mathrm{pp}(-10.32 \%)$ & $-0.50 \mathrm{pp}(-4.24 \%)$ \\
\hline $20-24$ & $24.90 \%$ & $32.70 \%$ & $26.40 \%$ & 7.80 pp (31.33\%) & $-6.30 \mathrm{pp}(-19.27 \%)$ & $1.50 \mathrm{pp}(6.02 \%)$ \\
\hline $25-29$ & $27.10 \%$ & $32.80 \%$ & $30.00 \%$ & $5.70 \mathrm{pp}(21.03 \%)$ & $-2.80 p p(-8.54 \%)$ & $2.90 \mathrm{pp}(10.70 \%)$ \\
\hline $30-34$ & $26.90 \%$ & $32.00 \%$ & $29.80 \%$ & 5.10 pp (18.96\%) & $-2.20 \mathrm{pp}(-6.88 \%)$ & 2.90 pp (10.78\%) \\
\hline
\end{tabular}

Source: Eurostat (edat_Ifse_29) - data extracted in 29.04.2020 


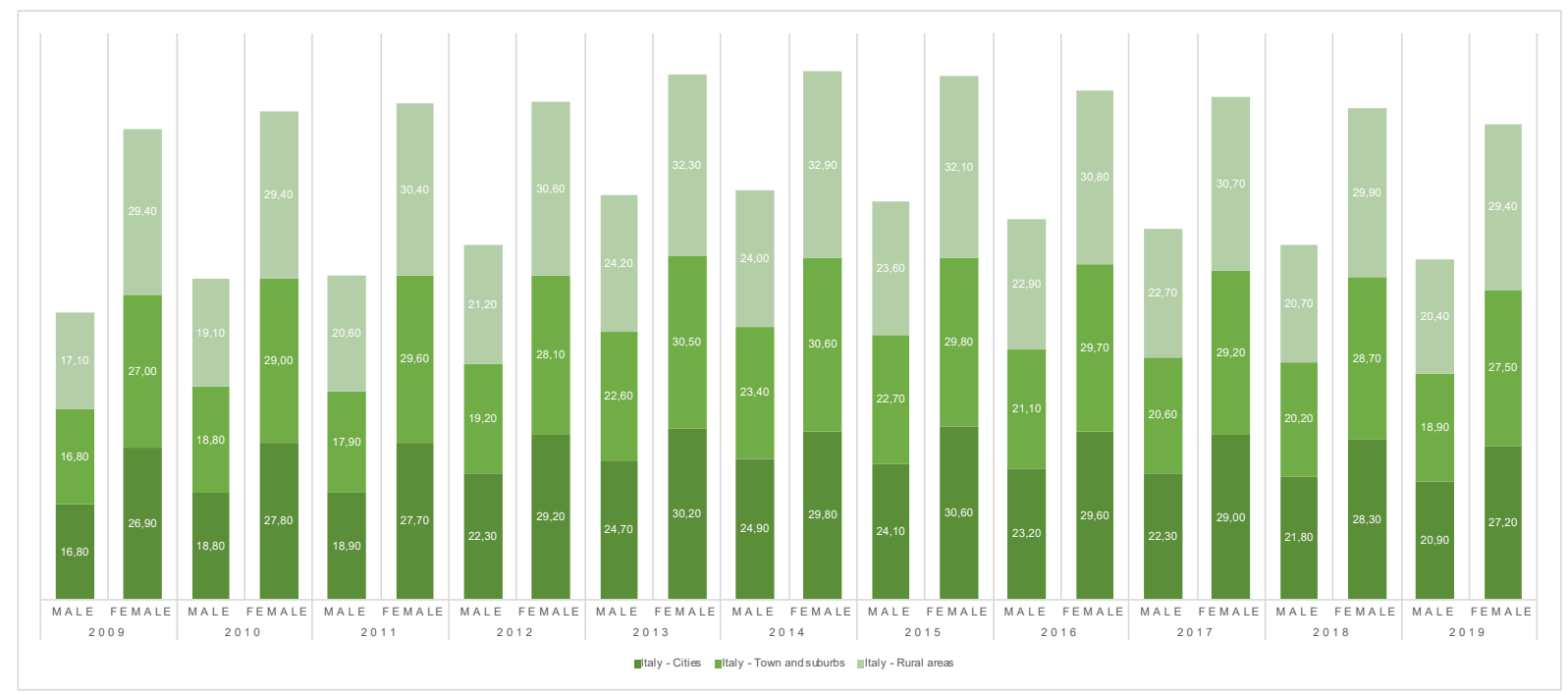

Source: Eurostat (edat_Ifse_29) - data extracted in 29.04.2020 
The chart below represents the percentages of NEETs relative to the different degrees of urbanisation from 2009 to 2019. In general, there has been an increase in NEETs percentages since 2009, culminating for cities in 2013 and in 2014 for towns and suburbs and rural areas. Following this peak, values start to decrease, although more slowly than they had increased from 2009 onwards.

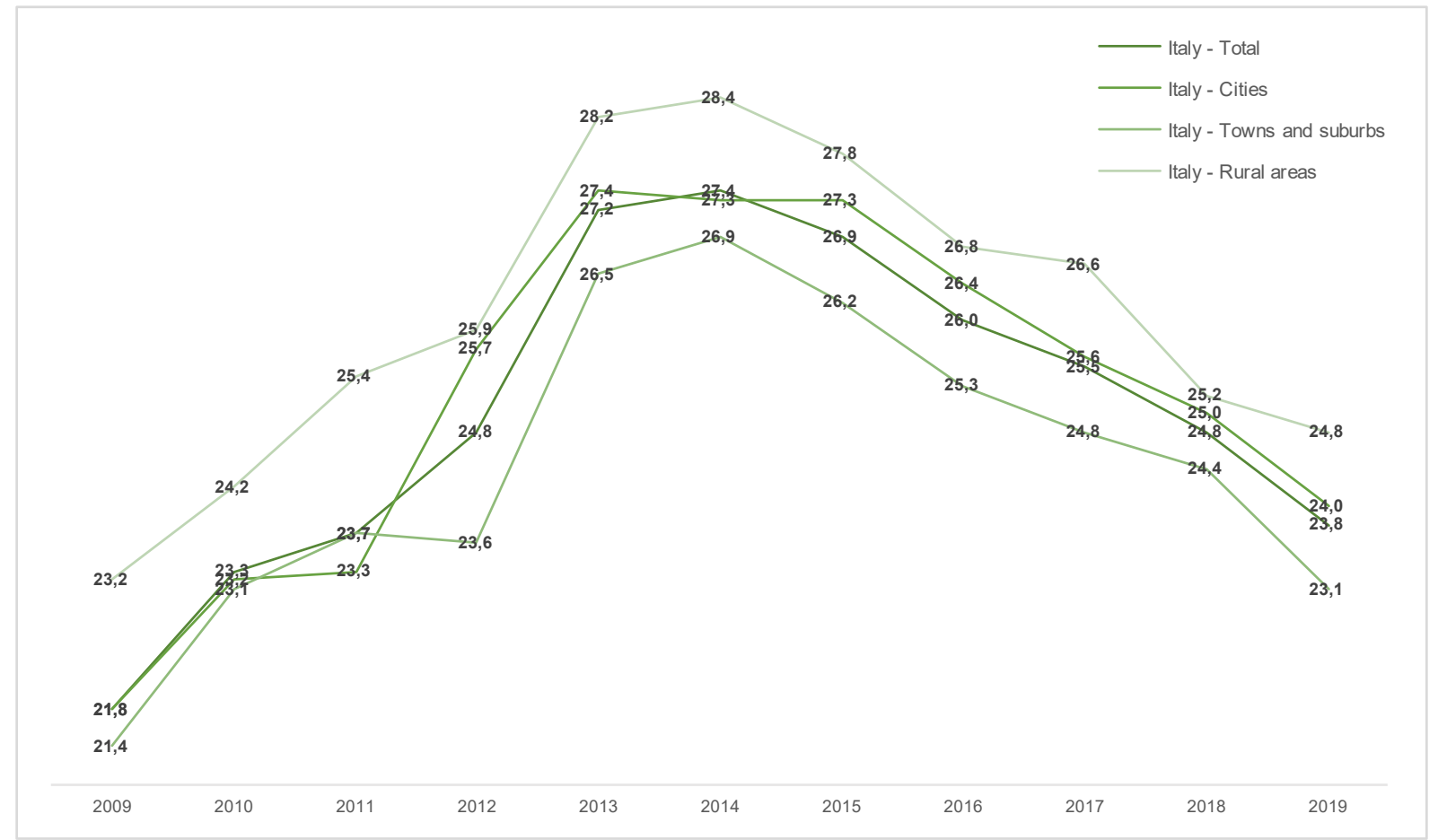

Source: Eurostat (edat_Ifse_29) - data extracted in 29.04.2020 


\section{CONCLUSIONS}

Youth population I The Italian population has slightly decreased from 2009 to 2019. Beyond the number of inhabitants, Italy, like many Western countries with developed economies, is going through a process of "dejuvenation" (Catabiano \& Rosina, 2018), i.e., an aging population due to a low birth rate. However, a notable point emerging from this data is the drastic decrease in the population living in the cities, with a corresponding increase of the population living in rural areas. From this it can be inferred that the economic crisis has also greatly affected the mobility of young Italians, who have been forced to stay/go back to their regions of origin due to the scarcity of opportunities and the high cost of cities.

Youth unemployment | Youth unemployment in Italy has risen dramatically since 2009, reaching a peak of $20 \%$ in 2014 and which then decreased significantly until 2019 . The trend has been linear with regards to rural areas and towns and suburbs. A separate discussion must be made for the cities, where the rates of de-occupation remained quite high, even in 2019 (17.10\%). This data confirms what was previously expressed concerning the period of difficulty experienced by cities.

Educational attainment | Between 2009 and 2019, the Italian population aged 15 to 24 years old has become more educated. The number of those with an education equivalent to ISCED-2 has decreased, while those with an education equivalent to ISCED 3-4 and ISCED 5-8 has increased.

ESLET I ESLET has strongly decreased in Italy. The trend is quite clear and linear for all three areas of urbanisation. However, from 2014 to 2018, the share slightly increased. The same thing happened for towns and suburbs and rural areas, from 2016 to 2018. In 2019, the share slightly decreased again in all the areas.

NEETs | Italy has been strongly affected by the economic crisis. The NEET rate is one of the highest in the EU and it increased overall from 2009 to 2019. The highest growth was seen between 2009 and 2014 but then decreased slightly until 2019. Concerning degrees of 
urbanisation, the highest rate is found in rural areas, although with a very small difference from the rate in cities and the national average. It is important to underline one thing about NEETs in the Italian context. The biggest differences are not found so much in different urban areas as in different national geographical areas. Southern regions have much higher NEET rates than the historically more industrialised northern regions (ISTAT, 2020). 


\section{REFERENCES}

Caltabiano, M., \& Rosina, A. (2018). The Dejuvenation of the Italian Population. Journal of Modern Italian Studies, 23(1), 24-40.

European Commission (2020). Youth Wiki: Italy.

Istituto Nazionale di Statistica. (2020). Istat, Popolazione residente al $1^{\circ}$ gennaio 2020 [Istat, Resident population as of January 1, 2020].

http://dati.istat.it/Index.aspx?DataSetCode=DCIS_POPRES1 


\section{IMPORTANT LINKS}

https://eacea.ec.europa.eu/national-policies/en/content/youthwiki/overview-italy

https://www.politichegiovanilieservisiocivile.gov.it/sx/dipartimento/competenze.aspx

https://www.politichegiovanili.gov.it/attivita/accordi-e-compartecipazioni/regioni/

https://ec.europa.eu/social/main.jsp?catld=1161\&langld=en\&intPageld=3340 